\title{
The vertical distribution of phytal ostracods in the intertidal zone at Gore Point, Bristol Channel, U.K.
}

\author{
DAVID J. HORNE \\ Department of Geology, City of London Polytechnic, Walburgh House, \\ Bigland Street, London E1 2NG
}

\begin{abstract}
The first detailed investigation of the vertical distribution of ostracods inhabiting intertidal algae is presented herein. A study was made of the ostracod faunas obtained from samples of Corallina collected at various levels along transects of the intertidal zone at Gore Point in the Bristol Channel. A total of 28 species were recorded, including four new species presently left in open nomenclature. Both the composition of the ostracod tauna and the population age structure of individual species were found to vary considerably according to tidal level. The development of instars apparently proceeds at a faster rate at higher tidal levels, probably due to higher mean annual water temperatures. Among the factors which may determine the percentage composition of the ostracod fauna at a given level are temperature, $\mathrm{pH}$, and the life-cycles and migratory habits of individual species.
\end{abstract}

\section{INTRODUCTION}

The relationship between ostracods and algae, and its importance in influencing ostracod distribution, has been demonstrated by several authors, such as Athersuch (1979), Hagerman $(1966,1968,1969)$, Whatley \& Wall $(1969,1975)$ and Williams (1969). This study, forming part of a wider investigation of intertidal ostracods in the Severn Estuary and Bristol Channel (Horne, MS 1980 ), is concerned with the vertical distribution of the ostracods inhabiting intertidal rock-pool algae at one site in the Bristol Channel.

Gore Point is situated at the western end of Porlock Bay, just outside the downstream limit of the Severn Estuary (Fig. 1). Backed by steep wooded slopes and low cliffs of Devonian grits and shales, the upper shore consists of a shingle bank which gives way at its base to a zone of large boulders extending to about mid-tide level. From mid-tide to low-tide level, the shore slopes more gently and is composed mainly of small boulders and cobbles, amongst which are many shallow pools. Occasional small pockets of sand and mud are to be found, especially around low-tide level. Westwards from Gore Point, the rocks forming the cliffs are also exposed over much of the intertidal zone, resulting in a more rugged shore profile. As the upper shore supports little algal growth, the lower shore is the main intertidal seaweed zone, with a cover of Fucus spp on rocks exposed at low water and an abundant and varied flora in the rock pools. Around the low-water mark of spring tides (LWST) a dense forest of Laminaria digitata and $L$. saccharina is exposed for brief periods. The rock pool flora is dominated by Corallina officinalis, Chondrus crispus, Ceramium rubrum and Laurencia pinnatifida, with Ulva lactuca being abundant in some of the very shallow pools. The intertidal flora of Gore Point has been described in detail by Smith (MS 1978).

The maximum spring tidal range at Gore Point is approximately $10 \mathrm{~m}$. Tidal and seasonal fluctuations of salinity are minimal (see Bassindale, 1943). In the main water body, salinity, temperature and $\mathrm{pH}$ values obtained at low water of spring tides in March, June and September, 1978 varied from $31.0-33.8^{\circ} \% 0,9.0-16.0^{\circ} \mathrm{C}$, and 8.2-9.6 respectively; greater variations were observed in rock pools isolated from the main water body at low tide, details of which are given in Fig. 2.

In order to investigate the vertical distribution of the ostracods inhabiting the algae in the rock pools, samples were collected at intervals along levelled transects measured from the high-water mark of spring tides (HWST) to the low-water mark of spring tides (LWST), on three separate occasions.

\section{METHODS}

To ensure constancy of sample type and to allow comparisons between samples taken on different occasions and at different localities, only the alga Corallina officinalis was collected. Sampling was not quantitative, but all the material was collected in plastic screw-topped jars of $125 \mathrm{ml}$ capacity, so that approximately equal volumes of weed were obtained. Algae were collected by placing a jar in the water adjacent to the weed which was then detached from the substrate and transferred to the jar as quickly as possibile to minimise any loss of material.

Within a few hours of collection, 30\% alcohol was added to each sample to fix the meiofauna. Samples were then washed through $2.00 \mathrm{~mm}$ and $63 \mu \mathrm{m}$ sieves, the finer fraction being retained and all the ostracods 


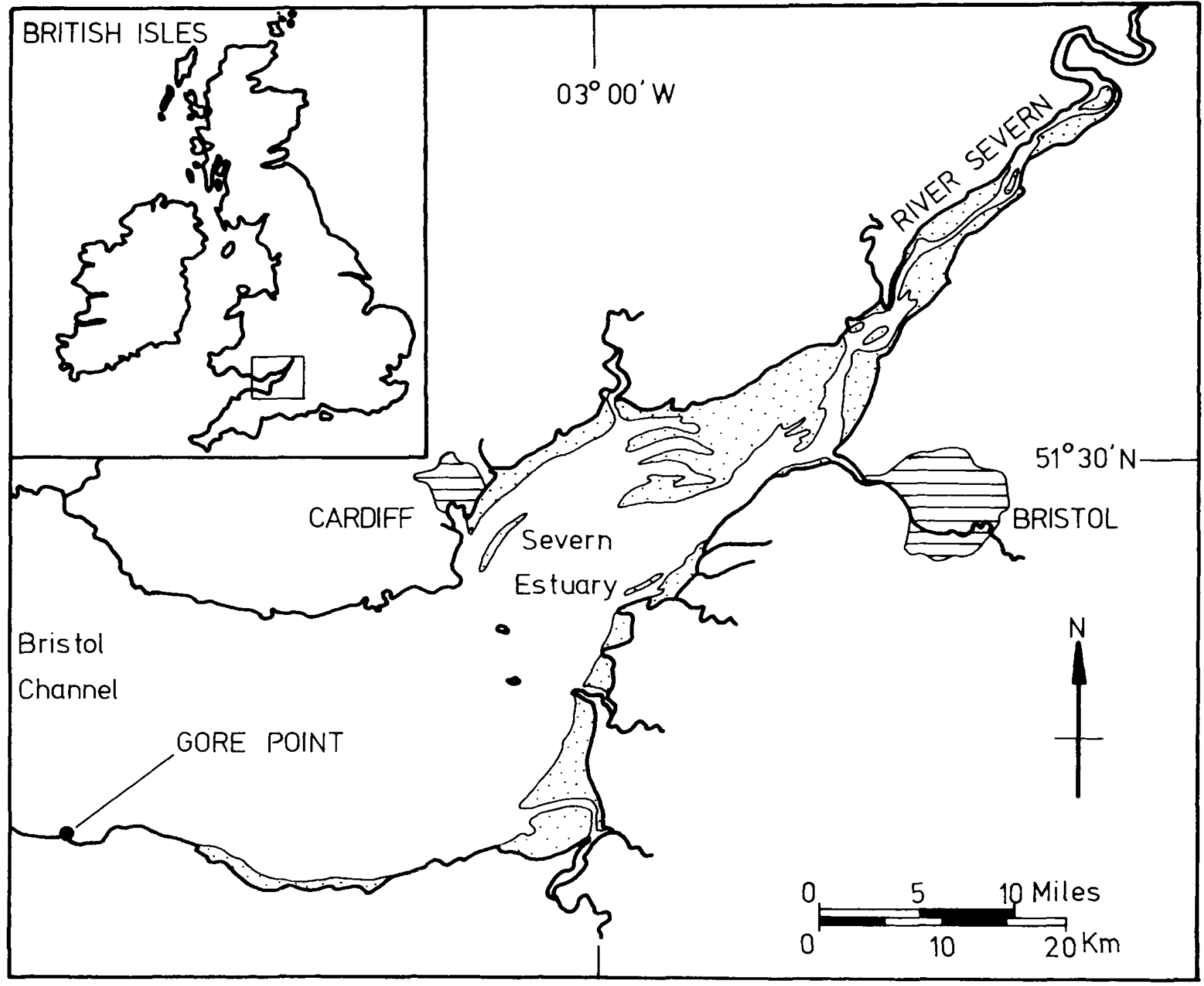

FIG. 1. LOCATION OF THE STUDY AREA

picked from it. Only "live" ostracods, those carapaces containing appendages and the soft, often coloured central part of the body, were picked. All specimens were mounted on standard micropalaeontological slides for identification and counting.

\section{THE TRANSECTS}

Transects were levelled using a cross-staff, consisting of a $1 \mathrm{~m}$ staff with a cross-bar at the top to which a spiritlevel was attached, in conjunction with a $2 \mathrm{~m}$ pole, graduated in $10 \mathrm{~cm}$ intervals. Vertical distances were measured by sighting along the cross-bar of the staff, horizontal distances were measured with a $30 \mathrm{~m}$ tapemeasure. Water temperature, salinity and $\mathrm{pH}$ were measured in the field using a mercury thermometer, an MC5 Salinity Bridge (made by Electronic Switchgear
Ltd) and a Mach Portable pH meter (Model 16400).

Transect A was surveyed and sampled on 14.9.77; samples were collected at five levels (A-E), all below mid-tide as Corallina was confined to less than $3 \mathrm{~m}$. above LWST on the part of the shore chosen (Fig.2). On 9.3.78, samples were collected along transect $\mathrm{B}$, a few hundred metres $W$. of transect $A$, where pools containing Corallina were found over a greater vertical range. A second sampling of transect B was carried out on 24.6.78. The levels at which samples were collected or measurements taken on transect $\mathrm{B}$ are designated $\mathrm{A}-\mathrm{H}$ in descending order (Fig.2); on 9.3.78, pools at levels B, C, E, F and $\mathrm{G}$ were sampled, while on 24.6.78, samples were obtained at levels $A, B, D, F$ and $G$. No Corallina was present on either occasion at level $\mathrm{H}$, although other algae were collected there. 
Fig. 2. Transects of the intertidal zone at Gore Point, Porlock.

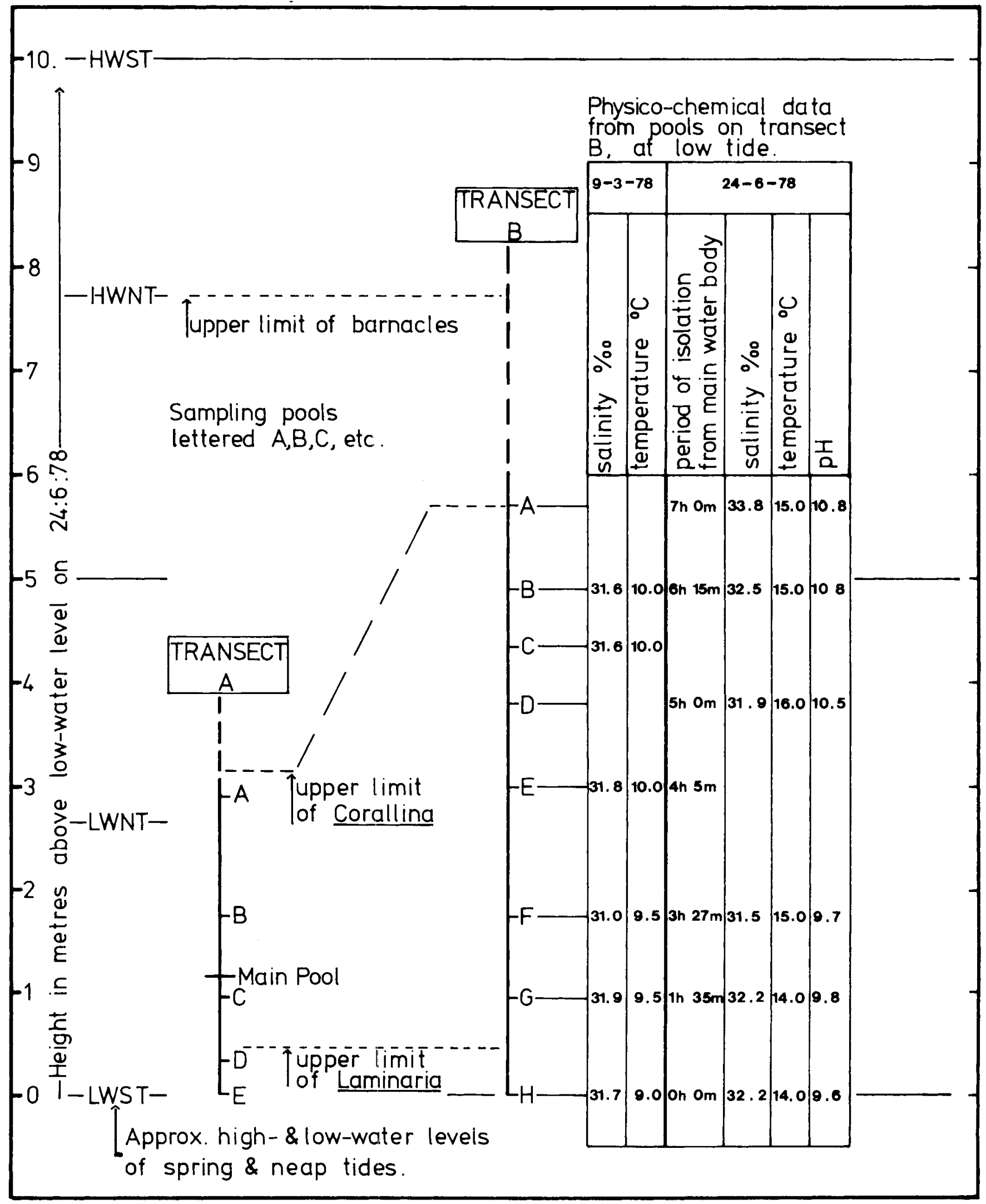


Table 1 Ostracods collected on transects of the intertidal zone at Gore Point

[Numbers obtained from $3 \times 125 \mathrm{ml}$ Corallina samples]

\begin{tabular}{|c|c|c|c|c|c|c|c|c|c|c|c|c|c|c|c|}
\hline \multirow{2}{*}{$\begin{array}{l}\text { Transect } \\
\text { Date } \\
\text { Level }\end{array}$} & \multicolumn{5}{|c|}{$\begin{array}{c}\text { A } \\
14: 9: 77\end{array}$} & \multicolumn{5}{|c|}{$\begin{array}{c}\text { B } \\
9: 3: 78\end{array}$} & \multicolumn{5}{|c|}{$\begin{array}{c}\text { B } \\
24: 6: 78\end{array}$} \\
\hline & A & B & C & $\mathrm{D}$ & $\mathrm{E}$ & B & $\mathrm{C}$ & $\mathrm{E}$ & $\mathrm{F}$ & $\mathrm{G}$ & A & B & $\mathrm{D}$ & $F$ & $\mathrm{G}$ \\
\hline H. villosa & - & 2 & 6 & 8 & 7 & - & - & - & - & - & - & - & 2 & 2 & 4 \\
\hline A. convexa & - & 32 & 84 & 132 & 79 & - & - & - & - & $\delta$ & - & - & 2 & - & 13 \\
\hline H. albomaculata & 2 & 26 & 9 & 14 & 5 & 3 & 1 & - & 8 & - & 32 & 110 & 474 & 132 & 71 \\
\hline L. rhomboidea & 25 & 18 & 62 & 284 & 202 & - & - & - & 6 & 19 & 1 & 27 & 43 & 26 & 30 \\
\hline H. viridis & - & - & - & - & - & 42 & 65 & 14 & 2 & 2 & 115 & 616 & 1690 & 72 & 11 \\
\hline Hemicytherura spp & 29 & 14 & 17 & 6 & 16 & 3 & - & 1 & 14 & 33 & - & 2 & 5 & 14 & 24 \\
\hline$P$. variabile & 37 & 1 & 1 & - & 2 & 48 & 20 & 7 & 249 & 142 & 65 & 244 & 425 & 423 & 501 \\
\hline$P$. sp. nov. A & - & - & - & - & - & 12 & 30 & 7 & 4 & 1 & 3 & 73 & 228 & 17 & 2 \\
\hline P. bradyi & 1 & 2 & 6 & 6 & 4 & - & - & - & - & 1 & - & - & - & - & 6 \\
\hline other spp & 12 & 15 & 6 & 14 & 18 & - & 1 & - & 3 & 10 & 3 & 10 & 23 & 29 & 27 \\
\hline TOTAL & 106 & 110 & 191 & 464 & 333 & 108 & 117 & 29 & 286 & 216 & 219 & 1082 & 2892 & 715 & 689 \\
\hline
\end{tabular}

Physico-chemical data collected on transect $\mathrm{B}$ on 9.3.78 and 24.6.78 are shown in Fig. 2. The data obtained at low tide on the latter occasion should be compared with salinity, temperature and $\mathrm{pH}$ values recorded at high tide about six hours previously of $31.5 \%, 14.0^{\circ} \mathrm{C}$ and 8.4 respectively. Only slight variations in salinity were observed on each occasion; $\mathrm{pH}$, on the other hand, showed considerable increases on 24.6.78, the highest value (10.8) being recorded in pool A which was isolated from the main water body for seven hours. The above data, though limited, are in agreement with the findings of other workers such that in the intertidal rock-pool environment, salinity variations tend to be minimal while temperature, and especially $\mathrm{pH}$, may show considerable diurnal fluctuations (Daniel \& Boyden, 1975; Pyefinch, 1943).

\section{THE OSTRACODA}

On all three occasions, three $125 \mathrm{ml}$ Corallina samples were collected at each of five levels. The numbers of ostracods given in Table 1 for each sampling pool are the combined totals from all three samples collected at that level. A total of fifteen $125 \mathrm{ml}$ samples were thus examined from each transect on each occasion. From transect $A$ on 14.9.77, a total of 1204 ostracods were obtained; the samples from transect B yielded only 756 ostracods on 9.3 .78 , but 5597 on 24.6.78. The greatest numbers occurred at the lower levels on both transect A on 14.9.77 and transect B on 9.3.78, while on transect $B$ on 24.6.78 the maximum abundance occurred rather higher up, at level D. At level E on transect B on 9.3.78, only 29 individuals were obtained. A possible explanation for the extreme paucity of ostracods in that particular pool became apparent on 23.6.78, when it was observed that while the falling and rising tides were at that level wave action was focussed on the pool by the form of the surrounding rocky shore; the repeated impacts of large volumes of water and the resultant excessive turbulence must have rendered the environment of pool E extremely inhospitable to any free-living organisms, despite the rich flora of Corallina. When sampling of transect $\mathrm{B}$ was repeated on 24.6.78, another pool (D) was selected in place of pool E.

A total of 28 species were recorded:

Aurila convexa (Baird, 1850)

Bythocythere bradyi Sars, 1926

Cythere lutea O. F. Müller, 1785

Cytheroma sp.

Cytheropteron dorsocostatum Whatley \& Masson, 1980

Hemicythere villosa (Sars, 1866)

Hemicytherura cellulosa (Norman, 1865)

Hemicytherura hoskini Horne, 1981

Heterocythereis albomaculata (Baird, 1838)

Hirschmannia viridis (O.F. Müller, 1785)

Leptocythere tenera (Brady, 1868)

Lindisfarnia laevata (Norman, 1865)

Loxoconcha rhomboidea (Fischer, 1855)

Paracytherois cf flexuosa (Brady, 1866)

Paracytherois sp. nov. A

Paradoxostoma abbreviatum Sars, 1866

Paradoxostoma bradyi Sars, 1928

Paradoxostoma normani Brady, 1868

Paradoxostoma sarniense Brady, 1868

Paradoxostoma variabile (Baird, 1835)

Paradoxostoma sp. nov. A

Paradoxostoma sp. nov. B

Paradoxostoma sp. nov. C

Sclerochilus sp. cf S. gewemülleri Dubowsky, 1939 
Semicytherura angulata (Brady, 1868)

Semicytherura nigrescens (Baird, 1838)

Semicytherura striata (Sars, 1866)

Semicytherura tela Horne \& Whittaker, 1980

Ten of the commoner species are illustrated in PI. 1.

Taxonomic notes. Two forms of Aurila convexa were found at Gore Point, differing in details of carapace morphology and colour. Both forms have been recorded by other authors as $A$. convexa from N.W. European localities. No adult males have been found, and the taxonomic status of the two forms remains unclear; they are therefore considered as one species for the purpose of this paper.

Lindisfarnia laevata is the form hitherto commonly known as Loxoconcha tamarindus (Jones) (see Horne \& Kilenyi, 1981).

\section{Vertical distribution}

The vertical distribution of the more important species from each transect is shown in the form of kite-diagrams in Figs. 3, 5 and 7 (note that different horizontal scales are used, although the vertical scale is the same in all three). Caution must be exercised in the interpretation of these diagrams, since the samples from which the data were obtained, while of similar size, were not truly quantitative. As an alternative, therefore, the percentage compositions of the faunas at each level are also shown, in Figs. 4, 6 and 8. A study and comparison of all six figures shows clearly that on each transect, both the overall faunal composition and the abundance of individual species varied considerably with respect to tidal level.

On transect A (14.9.77), Loxoconcha rhomboidea was most abundant at the lower levels (pools D and E), with decreasing importance up the transect, both numerically and in terms of percentage composition of the fauna. Similarly, Aurila convexa was abundant at lower levels, but was not found at the highest level sampled; numerically, its maximum was in pool $\mathrm{D}$, but in terms of percentage composition it. reached its greatest abundance higher up, in pool C. Conversely, Paradoxostoma variabile was of minor importance at lower levels, but relatively abundant at the top of the transect.

The data presentation for transect B (9.3.78) (Figs. 5 \& 6) may be somewhat misleading due to the previously mentioned sparse fauna obtained at level E,

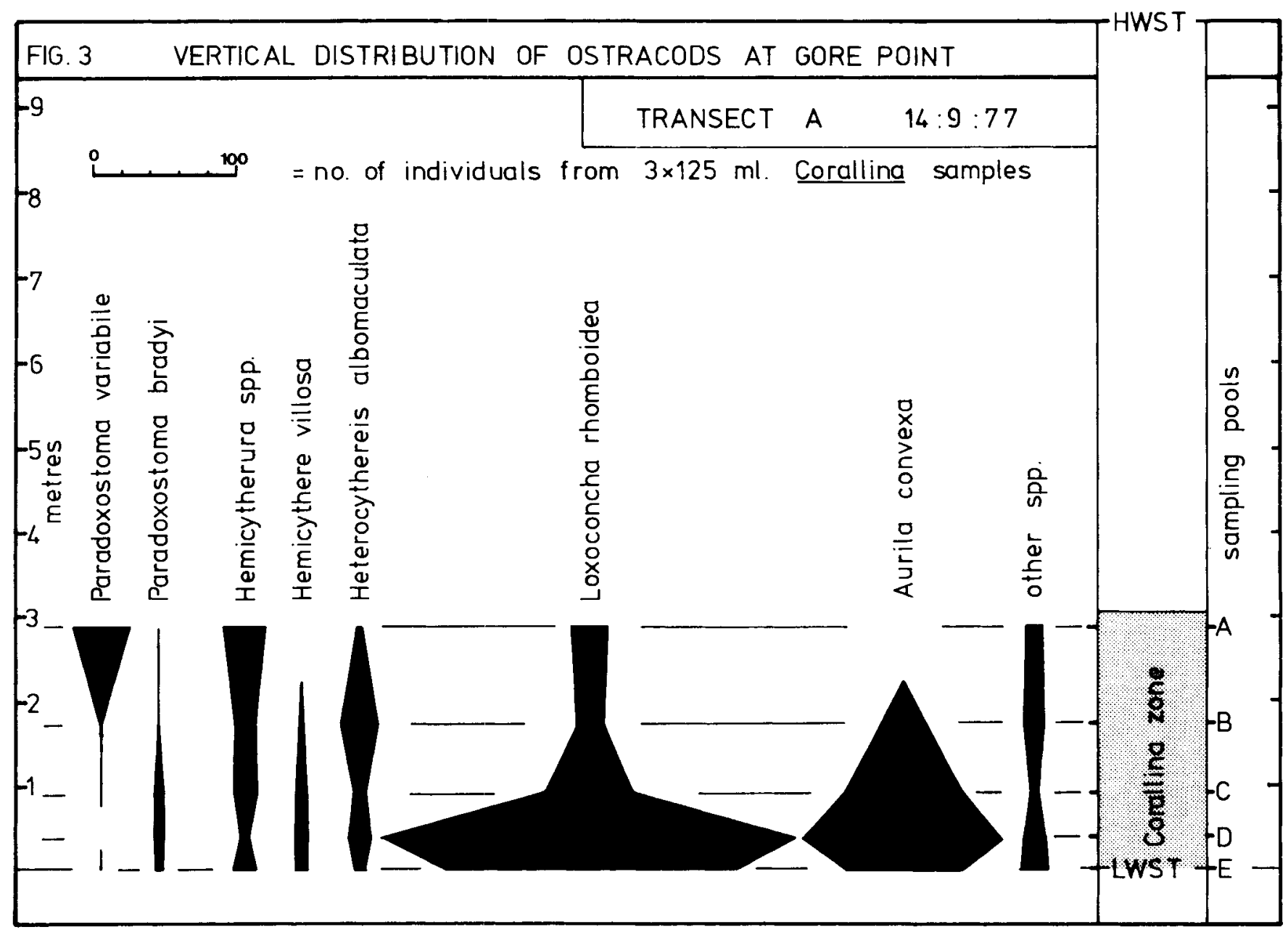




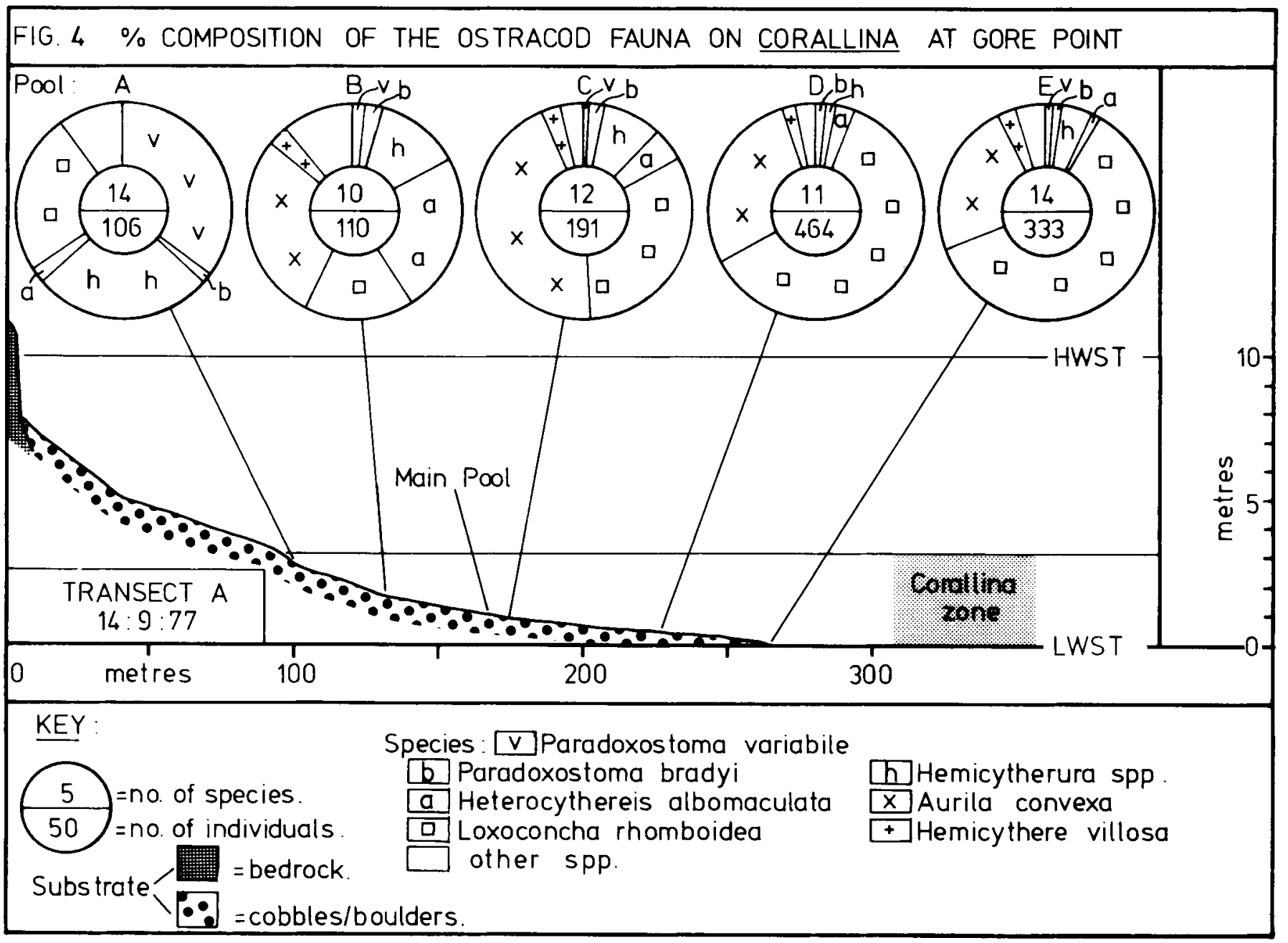

however, a number of observations may nevertheless be made. $P$. variabile was by far the most abundant species at the lower levels ( $F \& G$ ), while towards the top of the transect (B \& C) the importance of Hirschmannia viridis in the fauna increased considerably. L. rhomboidea and A. convexa were confined to the lower levels; Paradoxostoma sp. nov. A increased in abundance upwards, Hemicytherura spp. downwards.

In terms of percentage composition, the faunal variations on transect $B$ on 24.6.78 were essentially similar to those seen on that transect three months previously, with $P$. variabile dominating the low-level faunas ( $F \& G$ ) and $H$. viridis the higher levels (A, B \& D). In terms of actual numbers, $H$. viridis, Heterocythereis albomaculata and $P$. sp. nov. A all exhibited maxima at level $\mathrm{D} ; \boldsymbol{P}$. variabile was most abundant at the bottom of the transect $(G)$, with a general decrease in numbers upwards, especially above level $\mathrm{D}$.

\section{Population structure}

The abundance of ostracods on transect B on 24.6.78, in comparison with the relatively low numbers found three months earlier, can be largely attributed to reproductive activity during the intervening period by three species, $P$. variabile, $H$. viridis and $H$. albomaculata. The population structures on 24.6.78 at each level of each of these species are shown in Figs. 9-11. The populations of $H$. albomaculata and $H$. viridis consisted almost enirely of juveniles, which would have developed from eggs laid in the spring; the instars of the former would be expected to reach maturity by August or September to form an overwintering adult population, while those of the latter would pass the winter as latestage juveniles, maturing and reproducing the following spring (Hagerman, 1969; Horne, MS 1980). A detailed examination of the population structures of the two species shows clearly that they differed according to tidal level. In $H$. albomaculata, the A-5 and A-4 stages were dominant at the bottom of the transect; upwards, the percentage of larger instars steadily increased, so that at the highest level the A-2 stage was dominant. A similar pattern was exhibited by $H$. viridis, with the A-3 stage dominant at the bottom of the transect, the $A-1$ at the top. 


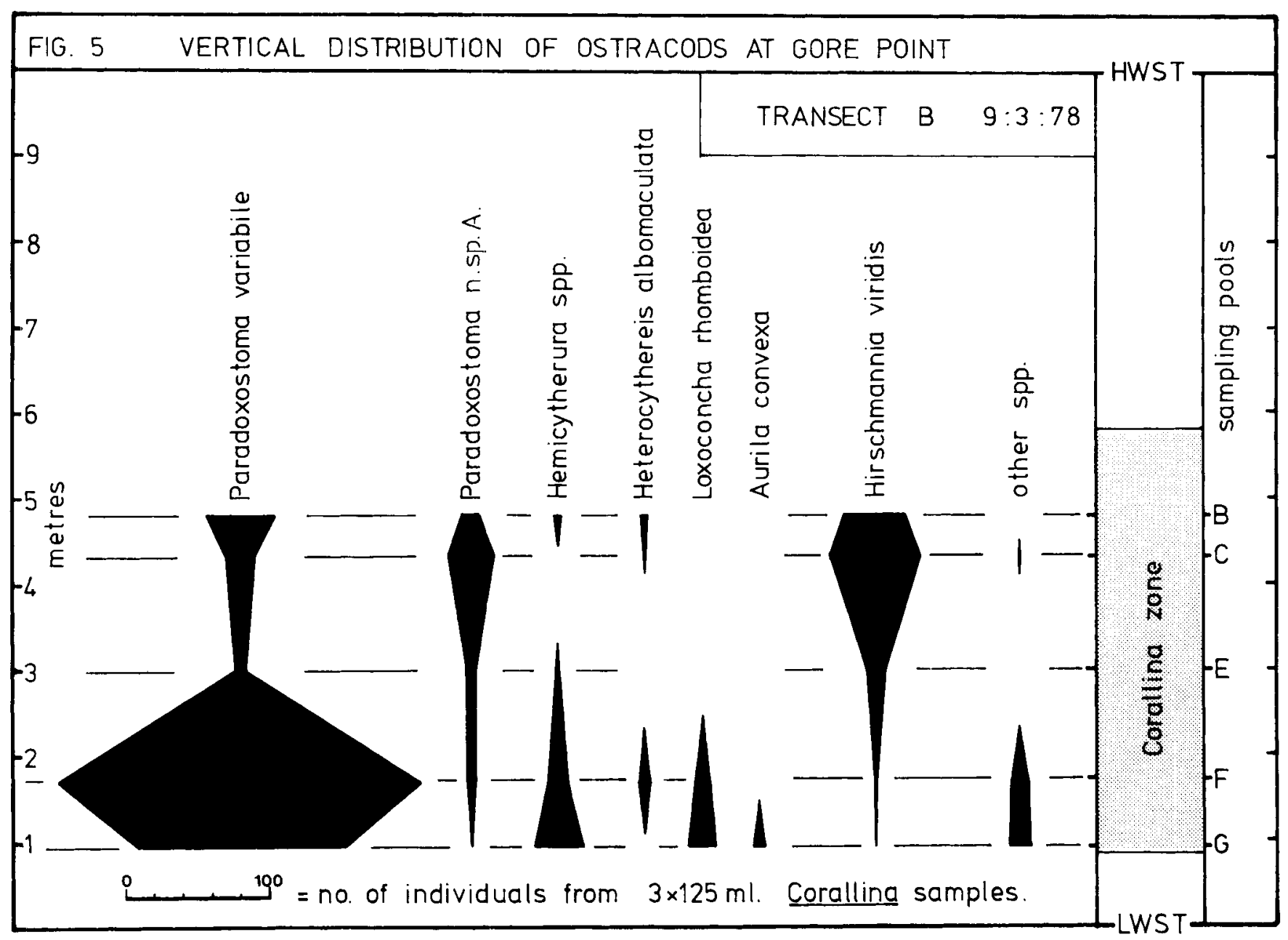

The population structures of $P$. variabile followed a similar, though less clearly defined pattern. At the lower end of the transect, small instars were dominant and adults were few; upwards, adults increased in numbers, reaching a maximum at level $D$, above which the trend towards increasing abundance of larger instars was no longer apparent, although adults remained dominant. $P$. variabile is apparently capable of reproducing throughout the year, although it reaches a maximum in the spring or early summer (Elofson, 1941; Hagermann, 1966; Horne, MS 1980).

The populations of all three of the above-mentioned species appear to have been at a more advanced stage of development at the higher levels than at the lower levels of the transect. This pattern could be attributed to the effects of differing temperature regimes at different tidal levels on the development of eggs and instars. High-level pools, being more often exposed to direct sunlight, are likely to have higher mean annual water temperatures than those at low levels, affecting the ostracods both directly (the development of eggs in particular is know to be temperature-dependant - see
Thiesen (1966)) and indirectly (by influencing food supply, such as diatoms), and resulting in faster growth rates at higher levels. A further contributing factor could be that at higher levels a reduction in the number of species competing for the same food allows faster development, through the absence or reduced numbers of species found in abundance at lower levels.

\section{DISCUSSION}

The above results demonstrate that both the composition of the ostracod fauna and the population structure of individual species vary with tidal level, at least as far as the faunas inhabiting Corallina at Gore Point are concerned. The reasons for this are unclear; the considerable fluctuations in temperature, $\mathrm{pH}$ and $\mathrm{O}_{2}$ levels that occur in intertidal pools (Daniel \& Boyden, 1975) may to some extent be responsible, although other factors should also be considered (e.g. competition with other organisms (such as copepods), qualitative and quantitative variations in food supply, and seasonal reproductive activity and migrations by the species concerned). 


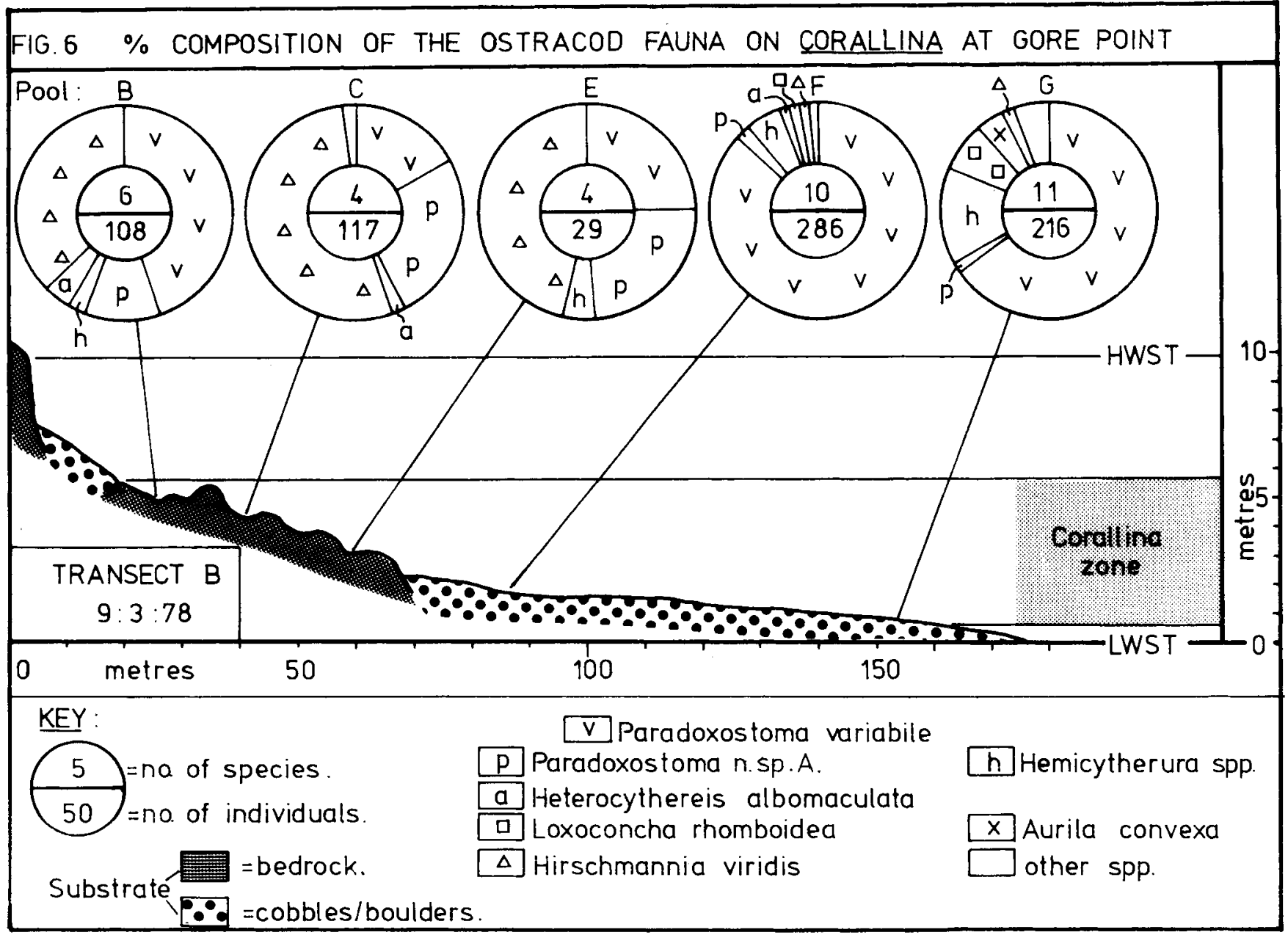

\section{Explanation of Plate 1}

SEM photographs of ostracods from Gore Point, collected on 14: 9: 77, transect A, level E (figs. 1, 2, 5, 6, 11-14), and on 24:6:78, transect B, levels D (figs. 3, 4) and F (figs. 7-10). All figures are external lateral views. All specimens deposited in the Bristol City Museum, numbered Ad 1301-1312.

Fig. 1. Hemicytherura cellulosa (Norman) (ó RV; $340 \mu \mathrm{m}$ long), Ad 1301.

Fig. 2. Hemicytherura hoskini Horne (of RV; $310 \mu \mathrm{m}$ long), Ad 1302.

Fig. 3. Hirschmannia viridis (O.F. Müller) (A-1 car., left side; $360 \mu \mathrm{m}$ long), Ad 1303.

Fig. 4. Hirschmannia viridis (O.F. Müller) (ócar., left side; $480 \mu \mathrm{m}$ long), Ad 1304 (note attached diatoms, and appendages protruding ventrally).

Fig. 5. Heterocythereis albomaculata (Baird) (ơ RV; $1100 \mu \mathrm{m}$ long), Ad 1305.

Fig. 6. Hemicythere villosa (Sars) ( $9 \mathrm{RV} ; 670 \mu \mathrm{m}$ long), Ad 1306.

Figs. 7-9 Paradoxostoma sp. nov. A: figs. 7, 8 (q RV \& LV; $490 \mu \mathrm{m}$ long), Ad 1307; fig. 9, detail of anteroventral region of fig. 8 .

Fig. 10. Paradoxostoma variabile (Baird) (ó LV; $760 \mu \mathrm{m}$ long), Ad 1308.

Fig. 11. Paradoxostoma bradyi Sars (\% LV; $740 \mu \mathrm{m}$ long), Ad 1309.

Fig. 12. Loxoconcha rhomboidea (Fischer) (ó RV; $700 \mu \mathrm{m}$ long), Ad 1310.

Fig. 13. Aurila convexa (Baird), form A ( $9 \mathrm{LV} ; 750 \mu \mathrm{m}$ long), Ad 1311.

Fig. 14. Aurila convexa (Baird), form B ( LV; $740 \mu \mathrm{m}$ long), Ad 1312.

Scale A: $200 \mu \mathrm{m}$ (figs. 1-4). Scale B: $200 \mu \mathrm{m}$ (figs. $5-8,10,11,13,14$ ); $50 \mu \mathrm{m}$ (fig. 9). Scale C: $200 \mu \mathrm{m}$ (fig. 12). 
PLATE 1
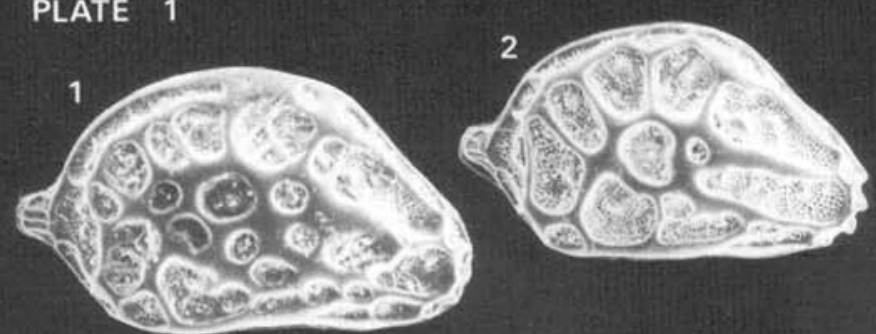

A.
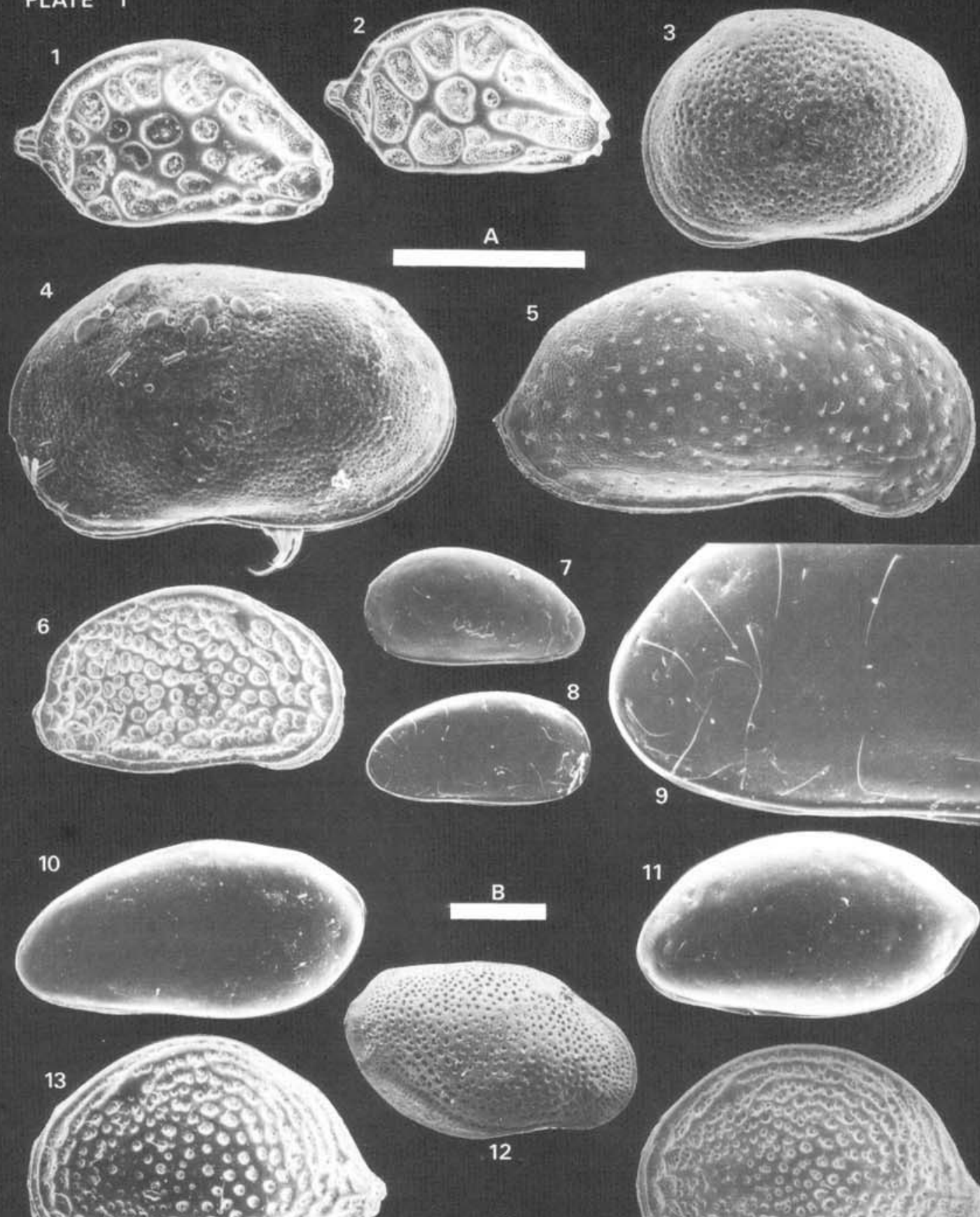

12
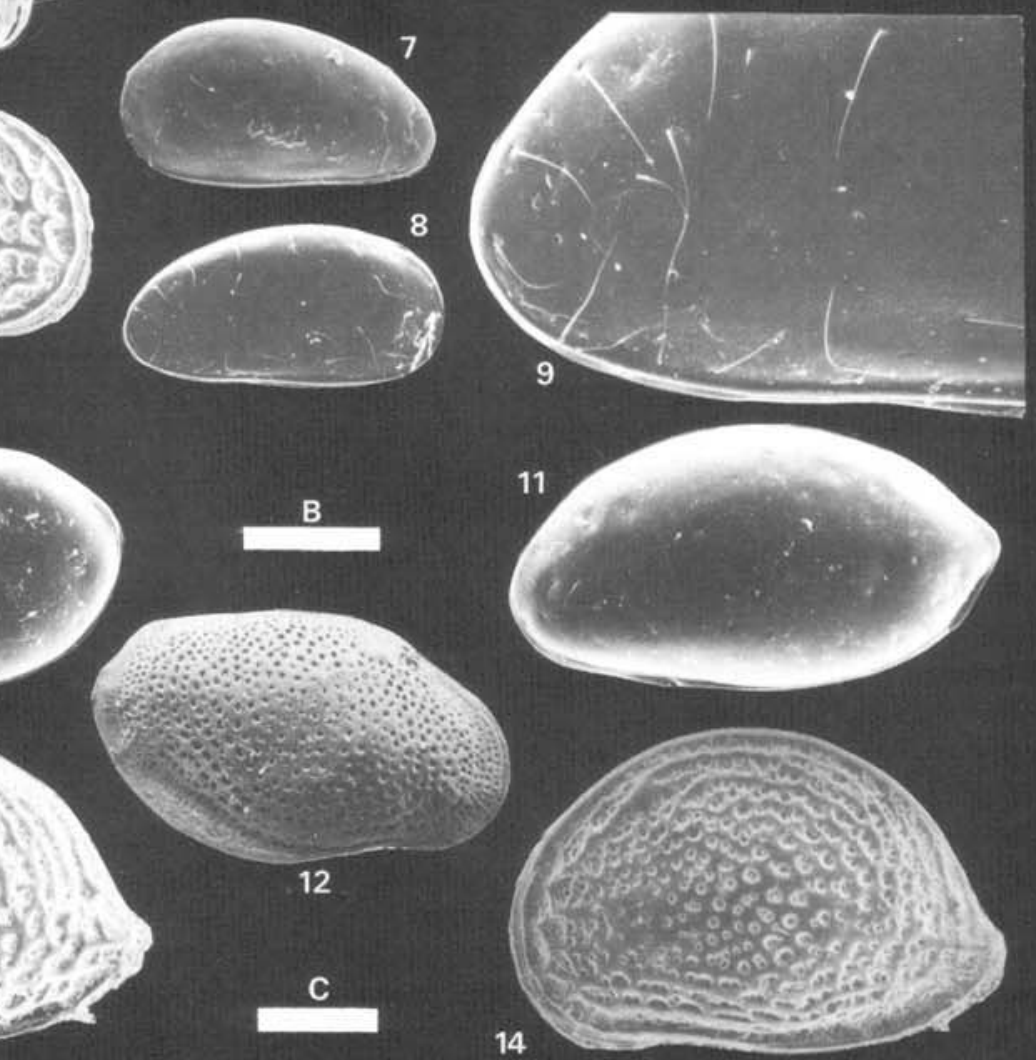
Seasonal fluctuations due to reproduction and especially migration by certain species almost certainly have some effect on the faunal composition at different levels. There is evidence (Whatley \& Wall, 1975; Horne, MS 1980) to suggest that $L$. rhomboidea, for example, migrates to low intertidal or upper sublittoral levels during the winter, this being supported by the present findings. This species has a life-cycle of one gencration per year, with overwintering eggs and adults (Elofson, 1941; Whittaker, MS 1972; Horne, MS 1980). On 14.9.77, populations consisting almost entirely of adults were present at every level sampled on transect $A$, though with a considerable increase in abundance towards the bottom of the transect - these would have been recentlymatured individuals beginning their down-shore migration. On 9.3.78, only a few specimens, mainly adults, were found at the lower end of transect $B$, while greater numbers, likewise nearly all adults, were found in a Laminaria holdfast sample taken at level $\mathrm{H}$ on that date this is consistent with the idea of overwintering adults confined to around LWST. Finally, on 24.6.78, popula- tions mainly of juveniles were found at every level on transect $B$, representing the new generation hatched from eggs laid the previous autumn before the migration of the adults. Similar seasonal migrations have been postulated by Whatley \& Wall (1975) for $H$. viridis, Cythere lutea and $H$. albomaculata.

The population structures of $H$. albomaculata, $H$. viridis and $P$. variabile on all three transects were consistent with what is known of their life-cycles. In the case of $P$. variabile, its virtual restriction to the top of transect A on 14.9.77 may be indicative of migration to higher levels during the late summer, perhaps in response to competition from other species which reach their reproductive maxima at that time.

Before any conclusions may be drawn with respect to a possible intertidal zonation scheme for rock-pool ostracods, further study is needed. A future investigation should determine whether or not the patterns of vertical distribution of ostracods are constant, or vary seasonally, and also whether lateral variations occur along the shore at different levels. There is little evidence for such

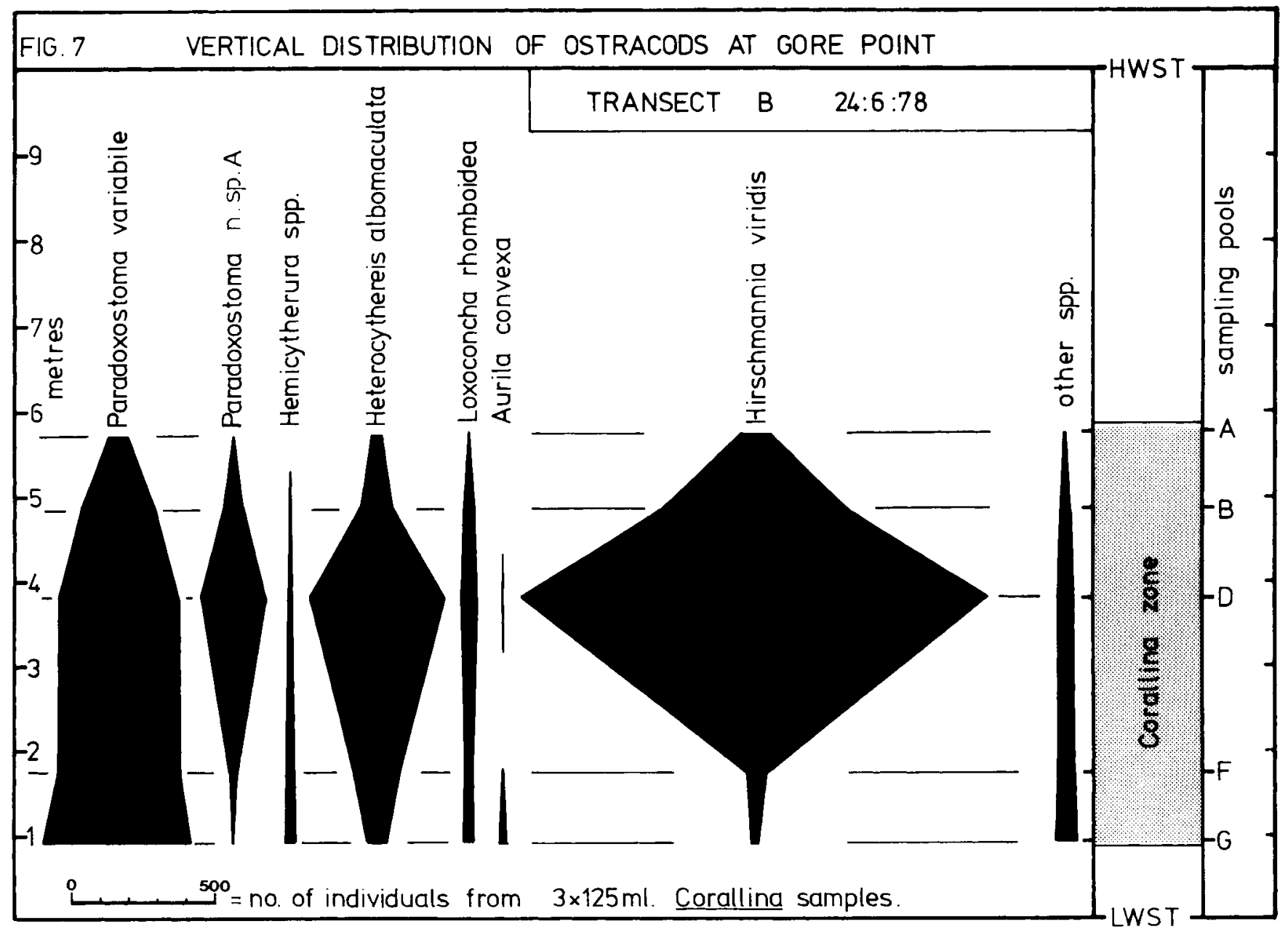




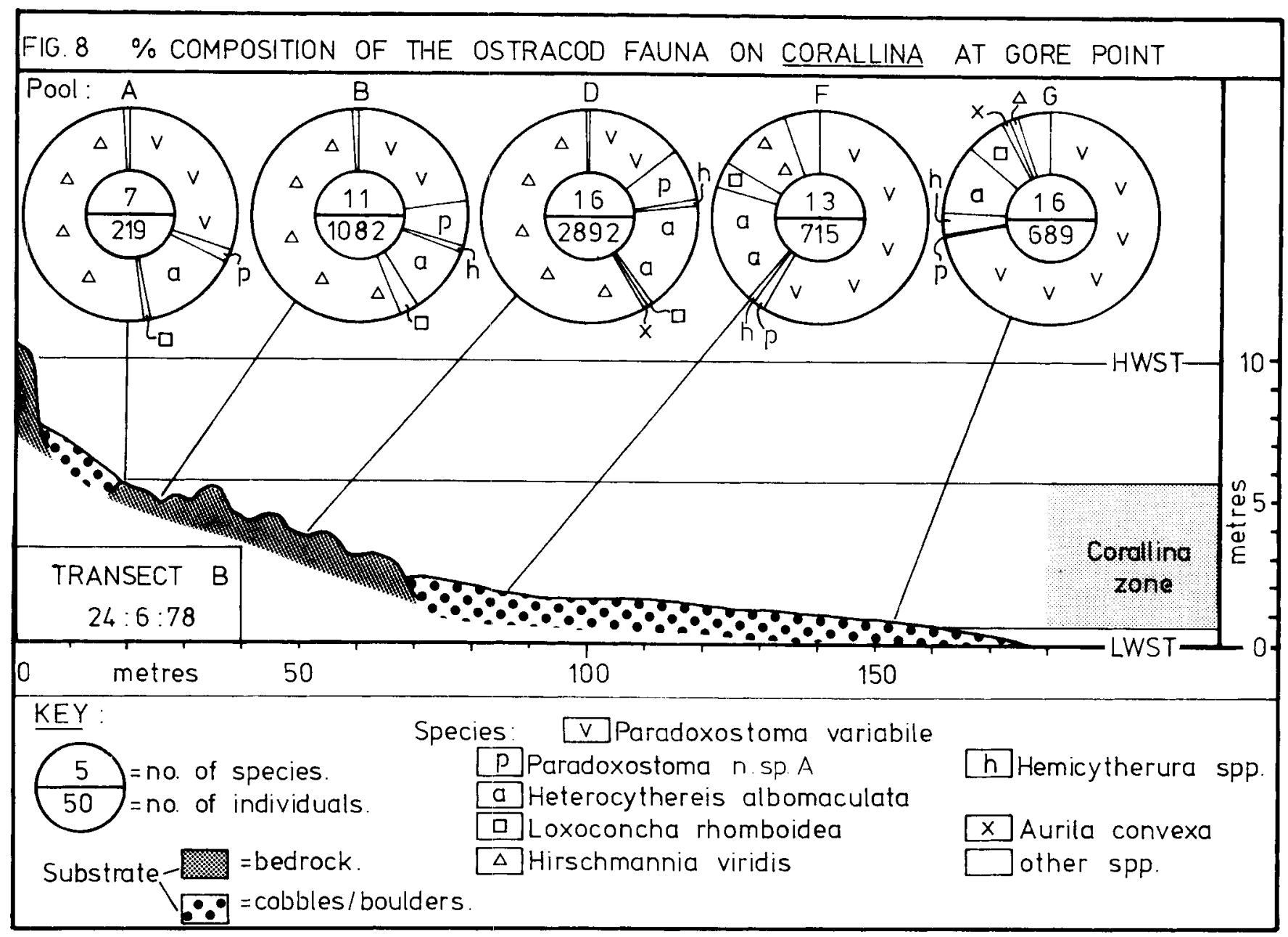

zonation in the work of previous authors, although it is well-known that certain other organisms inhabiting rock-pools do show preferences for particular tidal levels. Fraser (1936) observed the restriction of some copepods to certain levels in rock-pools in the Isle of Man, and noted that ostracods (four species) were particularly abundant at mid-tide level. Wieser (1952) found no correlation between the density of the phytal ostracod fauna and tidal level, considering only the overall fauna, but he did note such relationships in several other groups of organisms. Whatley \& Wall (1975) recognised a "critical level" at the boundary between the "upper" and "lower" sublittoral on the basis of phytal ostracod faunas, and some of their results hinted at a preference for certain intertidal levels (eulittoral and littoral fringe) by some species, although the many different types of algae sampled confused the issue in this respect. Finally, it should be borne in mind that the tidal range in the Severn Estuary and Bristol Channel is the largest in the British Isles $(10 \mathrm{~m}$. at Gore Point, $14 \mathrm{~m}$. at Avonmouth), a fact which may have some bearing on the vertical distribution of the ostracods; it has yet to be shown whether or not similar faunal variations with tidal level can be recognized in other localities where the range is smaller.

\section{ACKNOWLEDGEMENTS}

Much of this work was completed while I was a research student in the Geology Dept., Bristol University; financial assistance from the Bristol University Postgraduate Scholarship Fund and the Sabrina Project is gratefully acknowledged. I wish to thank Prof. D.L. Dineley and Dr. D. Hamilton (Geology Dept.), Dr. L. Smith (Botany Dept.) and Dr. C. Little (Zoology Dept.) for their advice and encouragement. The assistance of Mr. W. Dunne and Mr. I. Evans during the field work was much appreciated. Special thanks are due to Dr. J. Whittaker (British Museum (Natural History)) for his stimulating discussions and for reading and criticising the manuscript. I am grateful to Mr. W. Ralph (City of London Polytechnic) for his assistance in the preparation of the photographic plate. 

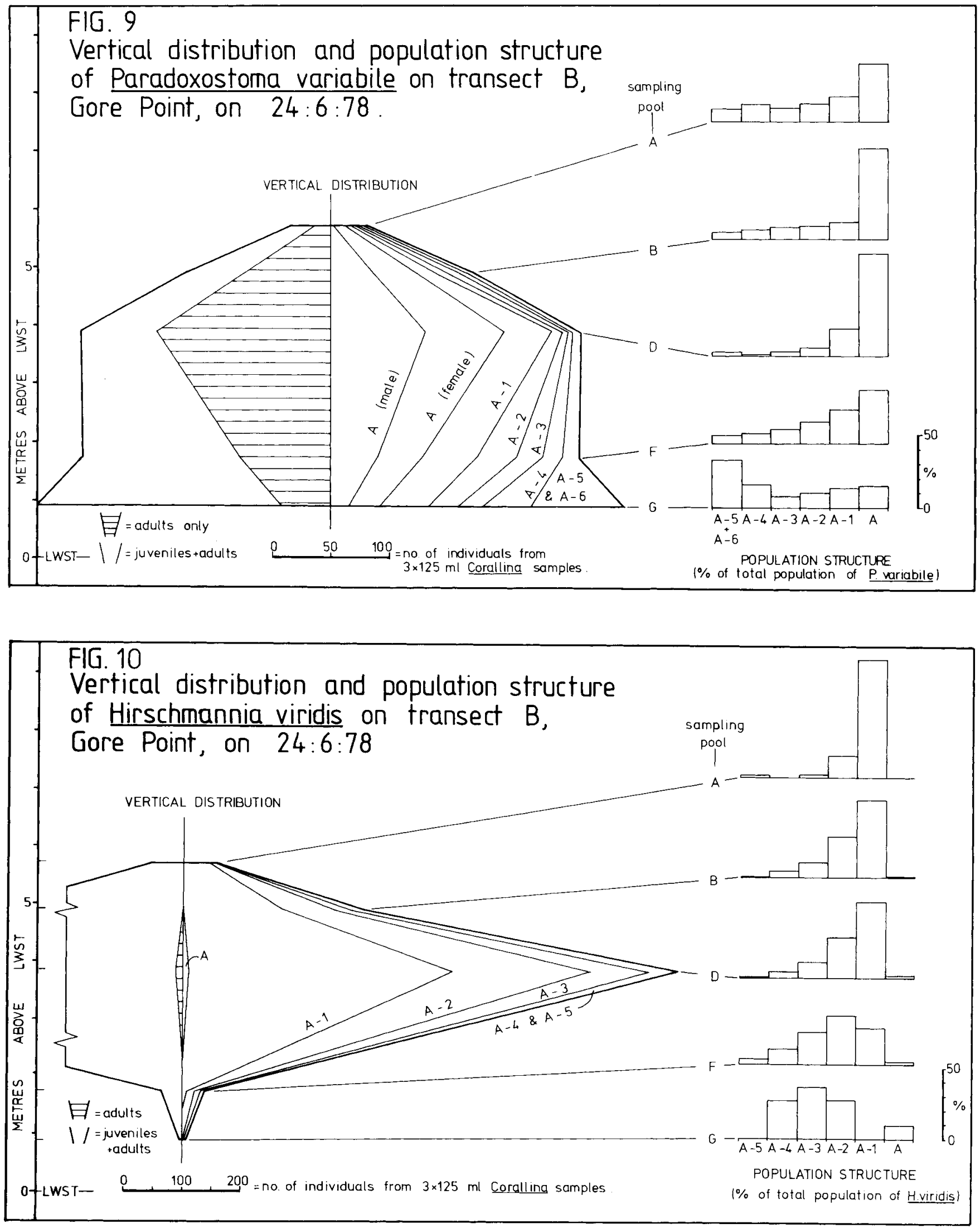


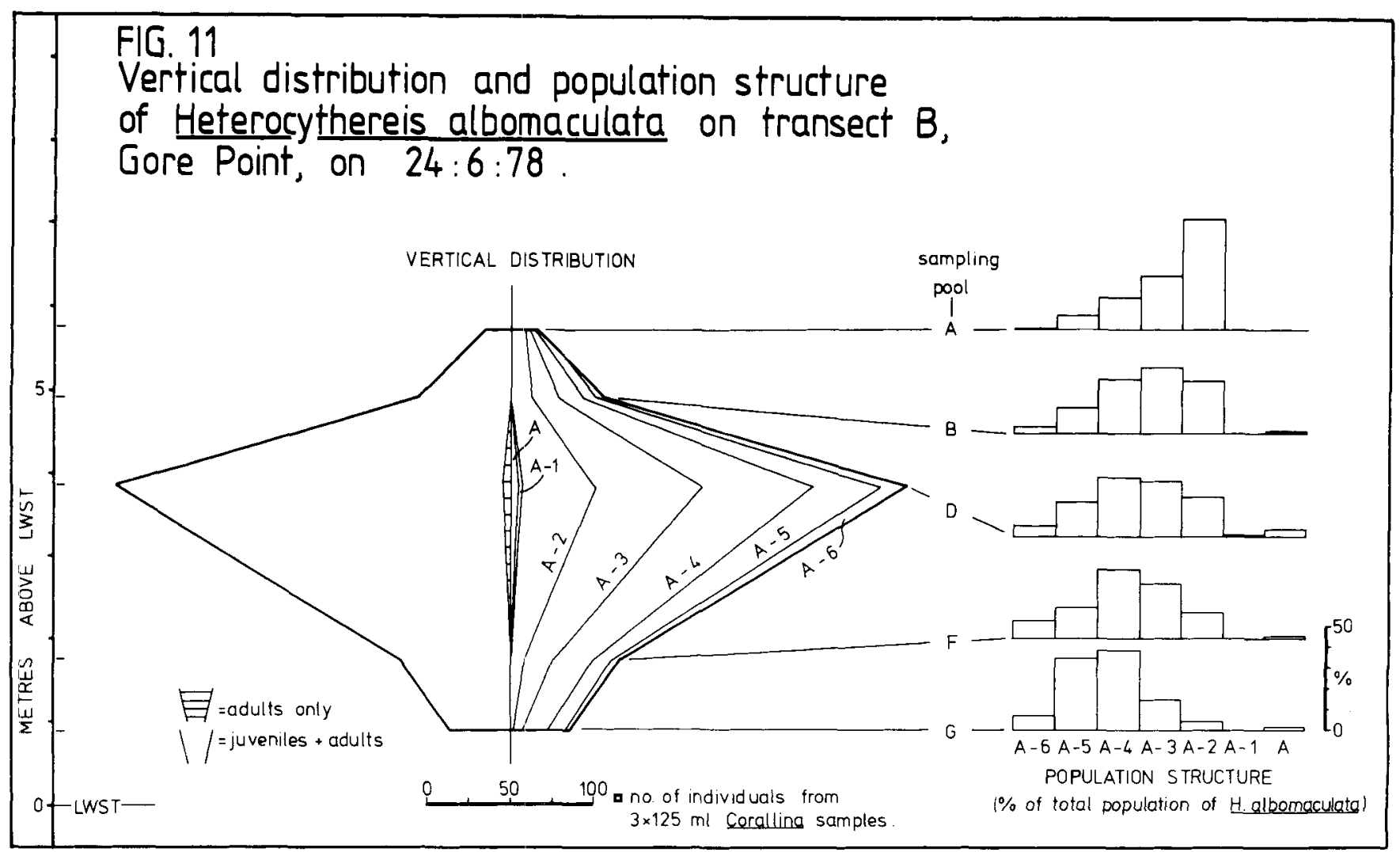

\section{REFERENCES}

Athersuch, J., 1979. The ecology and distribution of the littoral ostracods of Cyprus. J. nat. Hist., London, 13, 135-160.

Bassindale, R., 1943. Studies on the biology of the Bristol Channel, XI: The physical environment and intertidal fauna of the southern shores of the Bristol Channel and Severn Estuary. J. Ecol., London, 31, 1-29.

Daniel, M.J. \& Boyden, C.R., 1975. Diurnal variations in physico-chemical conditions within intertidal rockpools. Fld Stud., London, 4, 161-176.

Elofson, O., 1941. Zur kenntnis der marinen Ostracoden Schwedens mit besonderer Berücksichtigung des Skaggeraks. Zool. Bidr. Upps., 19, 215-334.

Fraser, J.H., 1936. The distribution of rock pool copepods according to tidal level.J. anim. Ecol., London, 5 (1), 23-25.

Hagerman, L., 1966. The macro- and microfauna associated with Fucus serratus L., with some ecological remarks. Ophelia, 3, 1-43.

Hagerman, L., 1968. The ostracod fauna of Corallina officinalis L. in western Norway. Sarsia, Bergen, 36, 49-54.

Hagerman, L., 1969. Environmental factors affecting Hirschmannia viridis (O.F. Müller) (Ostracoda) in shallow brackish water. Ophelia, 7, 79-99.
Horne, D.J. 1980. Recent Ostracoda from the Severn Estuary and Bristol Channel. Unpub. PhD thesis, University of Bristol.

Horne, D.J. \& Kilenyi, T.I., 1981. On Lindisfarnia laevata (Norman). Stereo-Atlas of Ostracod Shells, 8 (19), 107-116.

Pyefinch, K.A., 1943. The intertidal ecology of Bardsey Island, North Wales, with special reference to the recolonisation of rock surfaces, and the rock-pool environment. J. anim. Ecol., London, 12, 82-108.

Smith, L.P., 1978. The intertidal flora of the southern shores of the Severn Estuary. Unpub. PhD thesis, University of Bristol.

Thiesen, B.F., 1966. The life history of seven species of ostracods from a Danish brackish-water locality. Medd. Danm. Fisk. og Havunders., Copenhagen, 4, 215-270.

Whatley, R.C. \& Wall, D.R., 1969. A preliminary account of the ecology and distribution of Recent Ostracoda in the southern Irish Sea. In Neale, J.W. (Ed.), Taxonomy, morphology and ecology of Recent Ostracoda. Edinburgh, Oliver \& Boyd, 268-298.

Whatley, R.C. \& Wall, D.R., 1975. The relationship between Ostracoda and Algae in the littoral and sublittoral marine environments. Bull. Am. Paleont, 
Ithaca, 65 (282), 173-203.

Whittaker, J.E., 1972. The taxonomy, ecology and distribution of Recent brackish and marine Ostracoda from localities along the coast of Hampshire and Dorset. Unpub. PhD thesis, University of Wales, Aberystwyth.

Wieser, W., 1952. Investigations on the microfauna inhabiting seaweeds on rocky coasts: IV: Studies on the vertical distribution of the fauna inhabiting seaweeds below the Plymouth laboratory. J. mar. biol. Ass. U.K., 31, 145-174.

Williams, R., 1969. Ecology of Ostracoda from selected marine intertidal localities on the coast of Anglesey. In Neale, J.W. (Ed.), Taxonomy, morphology and ecology of Recent Ostracoda. Edinburgh, Oliver \& Boyd, 299-327. 